\title{
Two-Dimensional Nanoscale Imaging of Sugar Distribution Using AFM Force Sensing with Probe Modified by Concanavalin $A$
}

\author{
Shigeto Inoue, ${ }^{1,2}$ Yoshio Nakahara, ${ }^{1}$ Shinpei Kado, ${ }^{1}$ Mutsuo Tanaka, ${ }^{3}$ and Keiichi Kimura ${ }^{1 *}$ \\ ${ }^{\prime}$ Department of Applied Chemistry, Faculty of Systems Engineering, Wakayama University, \\ 930 Sakae-dani, Wakayama 640-8510, Japan \\ ${ }^{2}$ Analytical Science Research Laboratories, Kao Corporation, 1334 Minato, Wakayama 640-8580, Japan \\ ${ }^{3}$ Advanced Industrial Science and Technology, Central 5, 1-1-1 Higashi, Tsukuba, Ibaraki 305-8565 Japan \\ *kkimura@center.wakayama-u.ac.jp
}

(Received : October 24, 2011; Accepted : January 11, 2012)

We have recently realized the two-dimensional visualization of a oligoethyleneglycol $(O E G)$ /mannose (Man)-terminated pattern surface by performing AFM force measurements using a concanavalin $A$ (ConA)-modified AFM tip. To extend the visualization technique, various types of patterned surfaces with localized sugar chains were fabricated by lithography and their two-dimensional visualizations were challenged in a phosphate-buffered saline solution by AFM force measurements using a ConA-modified AFM tip in this study. The adhesion force based on the interaction of ConA with Man was much larger than that based on the interaction of ConA with phosphorylcholine or galactose. The spatial resolution of this method was evaluated using a nanopatterned surface fabricated using silica nanoparticles. Man-terminated regions were clearly distinguishable from $O E G$-terminated regions on a nanometer scale.

\section{Introduction}

The structure of sugar chains on glycoproteins and glycolipids is one of the determining factors for biological reactions on cell surfaces since intercellular communication is thought to occur when sugar-binding proteins (lectins) recognize sugar chains on a cell surface. Sugar chain recognition by lectin has also been found to play key roles in pathological processes including inflammatory and immunological responses, cell-cell recognition, cancer metastasis, and viral infection [1-3]. Recent advances in mass spectrometric techniques have allowed compositional and structural changes of sugar chains that induce various responses to be elucidated, resulting in a deeper understanding of signal transduction and functional expression [4-5]. However, little is known about the two-dimensional distributions of sugar chains on biological surfaces in an aqueous environment on micrometer to nanometer scales due to their complexity and diversity.

Advanced analytical methods have been used to observe the dynamics and distributions of sugar chains on cell membranes. Lens-based fluorescence microscopy would be an ideal method for investigations on a subcellular level below $250 \mathrm{~nm}$ $[6,7]$, except that since fluorescence techniques require fluorescent labeling of sugar chains, they are not direct analytical methods. Electron microscopy can be used to observe fine structures of sugar chains in cell membranes, but observations must be performed in a high vacuum. As gold nanoparticles interact specifically with sugar chains, an analytical method for investigating sugar chains has been developed that involves evaluating the distribution of gold nanoparticles adsorbed on cell membranes by scanning electron microscopy [8]. However, this method requires special equipment to be performed in the atmosphere. Thus, it is currently very difficult to observe the two-dimensional distributions of sugar chains on biological membranes in an aqueous environment.

Atomic force microscopy (AFM), which can be easily performed in an aqueous environment, is a 
promising method for obtaining in-situ high-resolution images of surface structures [9]. In addition, AFM force spectroscopy is widely used in various fields to detect interaction forces between two compounds. For example, AFM force studies on specific host-guest
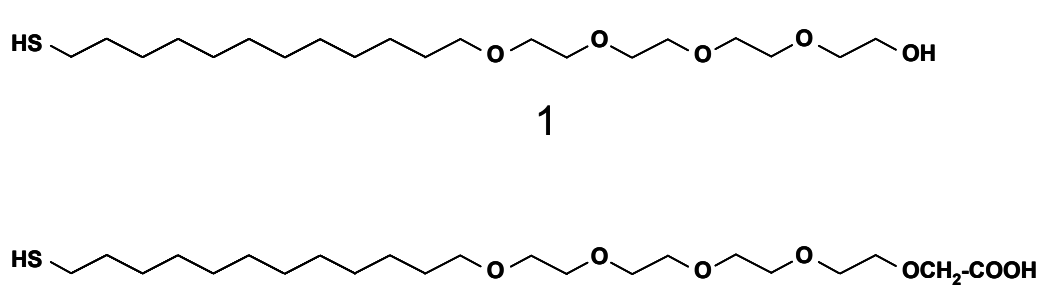

2 interactions in artificial host molecules (e.g., cyclodextrin [10], crown ether [11], and calixarene [12]) have been performed. In recent years, recognition phenomena in biomolecules

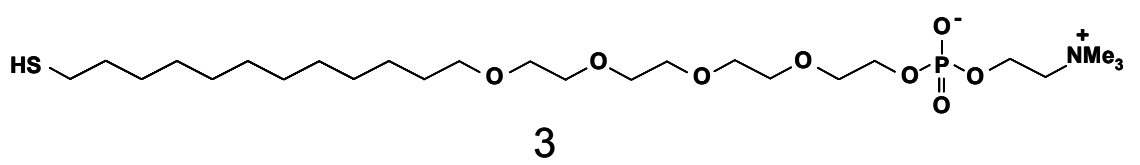

Figure 1. Molecular structure of functionalized thiol derivatives used in this study.
[13], antigen-antibody interaction [14], sugar chain-lectin recognition [15], protein unfolding [16], cell-protein interaction [17] and cell adhesion [18] have been investigated by AFM force measurements. In these measurements, a biomolecule is attached to an AFM tip and it is used to probe a surface modified by a comprehensive biomolecule.

Lectins are proteins that can recognize specific sugar chains and are thus very useful probes for studying sugar chains on cell surfaces [1]. In particular, concanavalin $A(\operatorname{Con} A)$ is a well-known lectin with specific affinities for $\alpha$-D-mannosyl and $\alpha$-D-glucosyl residues [19]. The interaction forces between Con $A$ and corresponding simple sugars have been studied by AFM [15,20]. Furthermore, the two-dimensional visualization of the sugar chain distribution has been attempted using the force-volume technique [21]. However, it has not been adequately verified whether the force-volume images obtained in these studies accurately depict the sugar chain distribution. To confirm the validity of these images, it is necessary to use a sugar-patterned surface whose structure has been unambiguously determined. Against this background, we have recently realized the two-dimensional visualization of a mannose (Man)/oligoethyleneglycol $(O E G)$-terminated pattern surface by performing AFM force measurements using a ConA-modified AFM tip [22]. As the structure of the patterned surface was clearly known here, we confidently concluded that the mapping based on the specific interaction force between ConA and Man accurately depict the sugar chain distribution. The present study seeks to extend our visualization technique. Various types of sugar-patterned surfaces were fabricated using functionalized thiol derivatives (Figure 1) and their two-dimensional distributions were visually mapped in a phosphate-buffered saline (PBS) on micrometer and nanometer scales by performing AFM force measurements using a ConA-modified AFM tip.

\section{Experimental}

\subsection{Materials}

Highly purified concanavalin $A$, D-(+)-mannose, ammonium carbonate, $N$-hydroxysuccinimide (NHS), and water-soluble carbodiimide hydrochloride (WSC) were purchased from Sigma-Aldrich (St. Louis, MO, USA). Amination of mannose was performed by the Kochetkov reaction [23]. PBS (pH 7.4) was purchased from Takara Bio (Tokyo, Japan). Deionized water (conductivity: $18 \mathrm{M} \Omega \mathrm{cm}^{-1}$ ) was prepared using a Milli-Q system. D-Mannosamine hydrochloride and D-galactosamine hydrochloride were purchased from Nacalai Tesque (Kyoto, Japan). Tetraethylene glycol/dodecane conjugate thiol 1, acetic acid/tetraethylene glycol/dodecane conjugate thiol $\mathbf{2}$, and phosphorylcholine (PPC)/tetraethylene glycol/dodecane conjugate thiol 3 (Figure 1) were prepared by the method given in Ref. 24. As sugar chains seem to be surrounded by PPC group of phospholipids moieties on the real biological membrane, mixed SAMs were also used in this study. Mica pieces were purchased from Merck (Darmstadt, 
Germany). They were typically $5-15 \mu \mathrm{m}$ in width and length. Silica nanoparticles (diameters: 50 and $100 \mathrm{~nm}$ ) were kindly donated by Fuso Chemical Co., Ltd. (Osaka, Japan). Silicon substrates were purchased from Nilaco Co. (Tokyo, Japan).

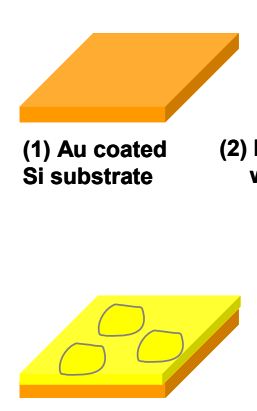

(4) Au deposition

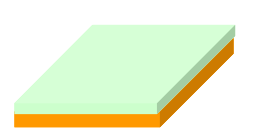

2) Formation of SAM with thiol A

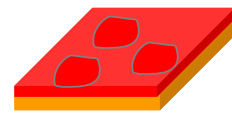

(5) Formation of SAM with thiol B

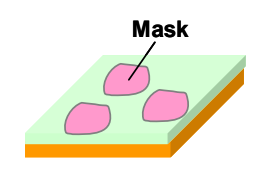

(3) Deposition of mica or silica particle as mask

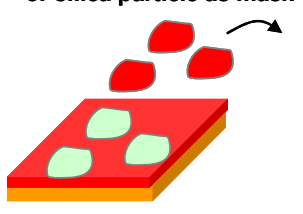

(6) Removal of mask
Figure 2. Schematic drawing of fabrication procedure of patterned substrate.

\subsection{Preparation of PPC/Man-terminated patterned surface}

The sugar-patterned surfaces were fabricated on a gold-coated silicon substrate by the lithography method shown as follows. Figure 2 shows a schematic diagram of the method. A gold-coated $(50 \mathrm{~nm})$ silicon substrate was immersed in an ethanol solution containing compound $3(1.0 \mathrm{mM})$ for $24 \mathrm{~h}$. The resulting self-assembled monolayer (SAM) was rinsed with ethanol and dried with nitrogen. Next, mica pieces were deposited on the substrate. A gold layer was then deposited on the substrate by vacuum evaporation and the substrate was immersed in an ethanol solution containing compounds $2(1.0 \mathrm{mM})$ and $\mathbf{3}(1.0 \mathrm{mM})$ for $24 \mathrm{~h}$. The substrate was immersed for $30 \mathrm{~min}$ in an aqueous solution of WSC $(0.10 \mathrm{M})$ and NHS $(0.10 \mathrm{M})$. Following activation of the terminal $\mathrm{COOH}$, the substrate was rinsed with deionized water, dried with nitrogen, and immersed in an aqueous solution containing mannosylamine $(1.0 \mathrm{mM})$ for $3 \mathrm{~h}$. After rinsing with deionized water and drying with nitrogen, the mica pieces were removed from the substrate under running water.

\subsection{Preparation of Man/Gal-terminated patterned} surface
Man/Gal-terminated patterned surface was prepared by a similar method to that used to prepare the PPC/Man-terminated patterned surface. A gold-coated silicon substrate was immersed in an ethanol solution containing compounds $\mathbf{1}(1.0 \mathrm{mM})$ and $\mathbf{2}(1.0 \mathrm{mM})$ for $24 \mathrm{~h}$. After chemical modification by mannosamine, mica pieces were deposited on the substrate. A gold layer was then deposited on the substrate by vacuum evaporation and immersed in an ethanol solution containing compounds $\mathbf{1}(1.0 \mathrm{mM})$ and $\mathbf{2}(1.0 \mathrm{mM})$ for $24 \mathrm{~h}$. After chemical modification by galactosamine, mica pieces were removed from the substrate under running water.

\subsection{Preparation of OEG/Man-terminated nanopatterned surface}

An OEG/Man-terminated pattern surface was prepared by a similar method to that used to prepare the PPC/Man-terminated pattern surface with a minor modification. A gold-coated silicon was immersed in an ethanol solution containing compound $\mathbf{1}(1.0 \mathrm{mM})$ for $24 \mathrm{~h}$. After SAM formation, silica nanoparticles were deposited on the substrate. A gold layer was then deposited on the substrate by vacuum evaporation and immersed in an ethanol solution containing compounds $1(1.0 \mathrm{mM})$ and $2(1.0 \mathrm{mM})$ for $24 \mathrm{~h}$. After chemical modification by mannosylamine for $3 \mathrm{~h}$, the silica nanoparticles were removed from the substrate under running water.

\subsection{AFM force measurements}

Gold-coated AFM cantilevers with a nominal spring constant of $0.025 \mathrm{~N} / \mathrm{m}$ (Olympus, Tokyo, Japan) were used for force measurements. Their spring constants were calibrated to be in the range $0.022-0.028 \mathrm{~N} / \mathrm{m}$ using the thermal noise method. All force measurements were performed in a PBS solution ( $\mathrm{pH}$ 7.4) using a NanoScope $\mathrm{V}$ Multimode AFM (Veeco, Santa Barbara, CA). All force curves were acquired using the AFM software provided by the manufacturer at a scan rate of $1 \mathrm{~Hz}$. The surface delay (defined as the delay between when the loading force reaches the target value and when the probe starts to retract) was set to $1 \mathrm{~s}$. A contact force of $200 \mathrm{pN}$ and a ramp size of $200 \mathrm{~nm}$ were used. Force curves were collected by the force-volume technique described in 
Ref. 25. This method allows force curves to be acquired as a function of the lateral position on the sample surface. A complete force curve was recorded at each position by raster scanning the AFM tip across the surface of the sample in a $64 \times 64$ point array. Height images $(64 \times 64$ pixels $)$ were simultaneously recorded by force-volume mapping. Following acquisition, AFM force-volume data were analyzed offline by a purpose-written program developed in our laboratory using Microsoft Visual Basic.

\subsection{Chemical modification of AFM tip}

A gold-coated AFM tip was immersed in an ethanol solution containing compound $2(1.0 \mathrm{mM})$ for $24 \mathrm{~h}$ and then rinsed with ethanol and dried with nitrogen. The tip was then immersed for $30 \mathrm{~min}$ in an aqueous solution containing WSC $(0.10 \mathrm{M})$ and NHS $(0.10 \mathrm{M})$. It was subsequently rinsed with deionized water and dried with nitrogen. Finally, the NHS-activated AFM tip was immersed in a PBS solution (pH 7.4) containing ConA $\left(0.10 \mathrm{mg} \mathrm{mL}^{-1}\right)$ for $2 \mathrm{~h}$ and rinsed with a PBS solution.

\section{Results and discussion}

\subsection{Fabrication of sugar-patterned surface}

The alkanethiols spontaneously form self-assembled monolayers (SAMs) on a gold substrate. As sugar moieties can be easily introduced into functionalized SAMs with reactive sites using chemical reactions, several patterned SAMs containing sugar chains have been successfully constructed on gold substrates [26]. In our previous study, an $O E G /$ Man-patterned surface was fabricated using compound 1 having an $O E G$ end and compound 2 having a carboxylic group end through the condensation reaction with mannosylamine. However, real biological membranes do not have $O E G$ chains; rather they have mixed surfaces with various phospholipids and other lipids. Therefore, a $P P C / M a n$-patterned surface was prepared in this study using compound 3 with a $P P C$ end with the aim of fabricating biomimetic surfaces. It is well known that $P P C$ also suppresses the non-specific adsorption of proteins [27].

The sugar-patterned surfaces were fabricated on a gold-coated $(50 \mathrm{~nm})$ silicon substrate by lithography using mica pieces or silica nanoparticles as masks [28]. Figure 2 shows a schematic diagram of the method used to fabricate the sugar-patterned surfaces. A gold-coated silicon substrate (1) was immersed in an ethanol solution containing thiol A for $24 \mathrm{~h}$ (2). The resulting SAM was rinsed with ethanol and dried with nitrogen. Next, mica or silica masks were deposited on the substrate (3). A gold layer was then deposited on the substrate by vacuum evaporation (4) and immersed in an ethanol solution containing thiol B for $24 \mathrm{~h}$ (5). Finally, the masks were removed from the substrate under running water (6). The completion of the pattern surface was confirmed by AFM topography. The terminal $\mathrm{COOH}$ of compound $\mathbf{2}$ was activated by immersion in an aqueous solution containing WSC and NHS for $30 \mathrm{~min}$. After rinsing with deionized water and drying with nitrogen, aminated sugars were introduced to the substrate through a condensation reaction for $3 \mathrm{~h}$.

\subsection{Two-dimensional mapping of PPC/Man-terminated patterned surface}

Figure 3 shows typical force curves obtained by ConA-modified tip for the PPC/Man-terminated pattern surface in a PBS solution. A characteristic adhesion force was obtained in the Man-terminated region that can be attributed to the specific adhesion force between ConA and Man; no such adhesion force was observed in the $P P C$-terminated region.

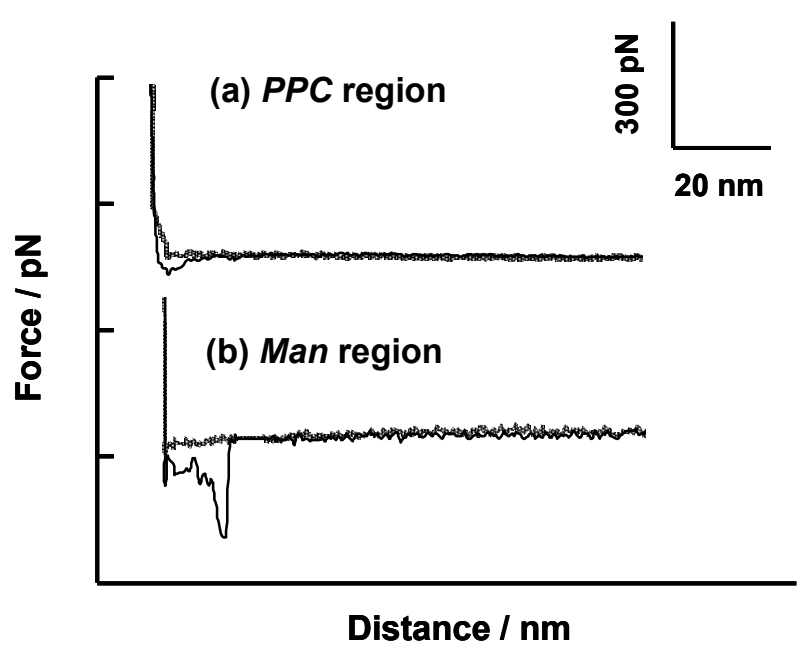

Figure 3. Typical AFM force curves obtained from (a) $P P C$-terminated, and (b) Man-terminated regions in a PBS solution. 


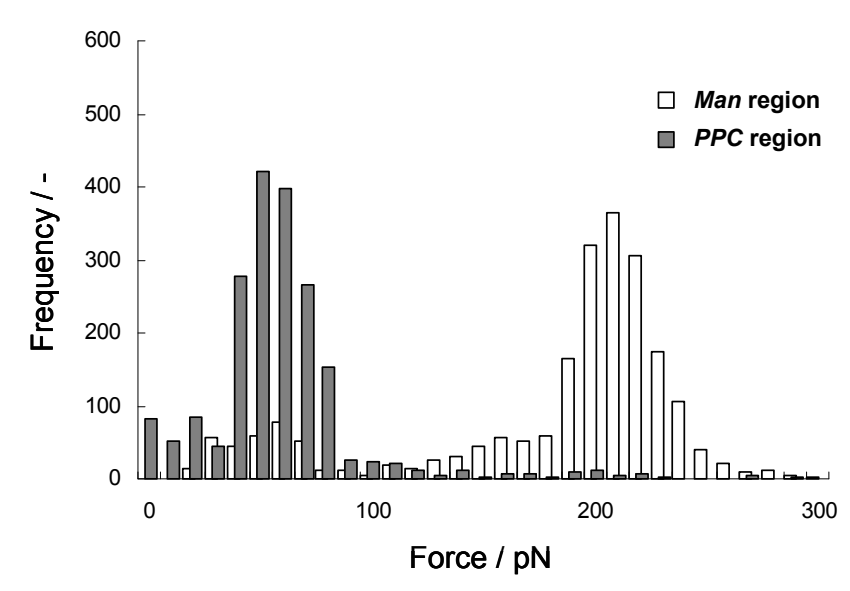

Figure 4. Histogram of adhesion forces obtained from $P P C$ and Man-terminated regions.

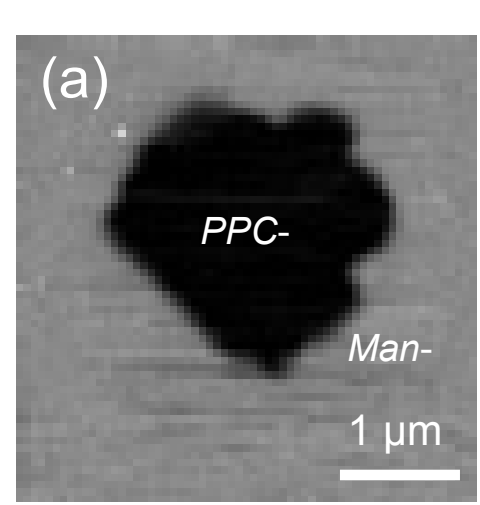

100

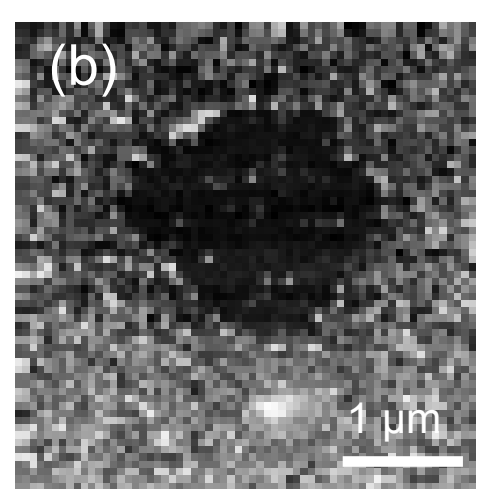

0.2
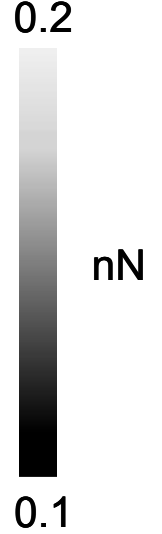

Figure 5. (a) Topological image and (b) adhesion force image of a PPC/Man-terminated patterned surface obtained using a ConA-modified tip in a PBS solution.

In the Man-terminated region, the specific adhesion force was approximately $200 \mathrm{pN}(207 \pm 27 \mathrm{pN})$, as shown in Figure 4. In contrast, in the $P P C$-terminated region, the non-specific adhesion force was approximately $50 \mathrm{pN}(55 \pm 11 \mathrm{pN})$. The non-specific interaction forces observed in the $P P C$-terminated region were as large as those previously observed in the $O E G$-terminated region [19].

We were anxious about the interference from the hydrophobic interactions and electrostatic attractive forces between the PPC group and the hydrophobic protein, ConA. However, the present measurement revealed that this interaction force is considerably smaller than that between ConA and Man. Consequently, Man-terminated regions could be clearly distinguished from other regions, as shown in Figure 5. It was thus demonstrated that the Man distribution can be visualized even on a surface that is similar to a biological membrane.

\subsection{Selective two-dimensional mapping of Man/Gal-terminated patterned surface}

It is well known that $\operatorname{Con} A$ has a specific affinity for Man among other sugar residues. A ConA-modified tip has the potential to be used as a probe for selective AFM mapping of Man based on its specific affinity.

We prepared a mixed sugar-patterned surface of Man and Gal to investigate the ability of the ConA-modified tip to selectively visualize Man by this method. Figure 6 shows typical force curves for the $\mathrm{Man} / \mathrm{Gal}$-terminated pattern surface in a PBS solution.

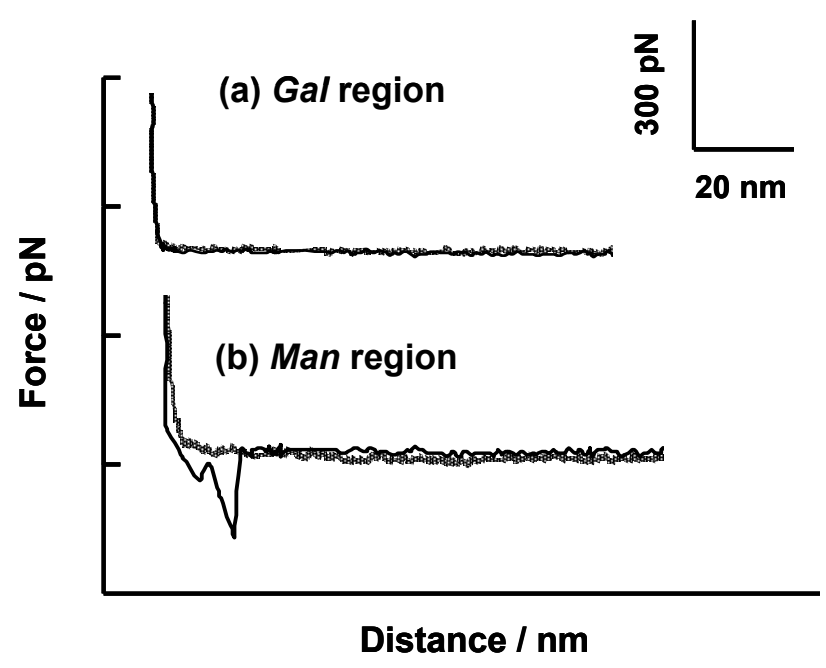

Figure 6. Typical AFM force curves obtained from (a) Gal-terminated, and (b) Man-terminated regions in a PBS solution. 
No significant specific force was observed in the Gal-terminated region like the $P P C$-terminated region. Thus, the Man-terminated regions can be selectively visualized in the mixed sugar-patterned surface (Figure 7). Accordingly, it may be possible to detect other sugar chains by attaching different lectins to the AFM tip. For some lectins, the interaction force of lectin with biological membranes may be too strong to detect the specific interaction force with the sugar chain. Thus, for practical applications, it is necessary to confirm the detection ability of individual lectins by performing systematic investigations using the method presented here.
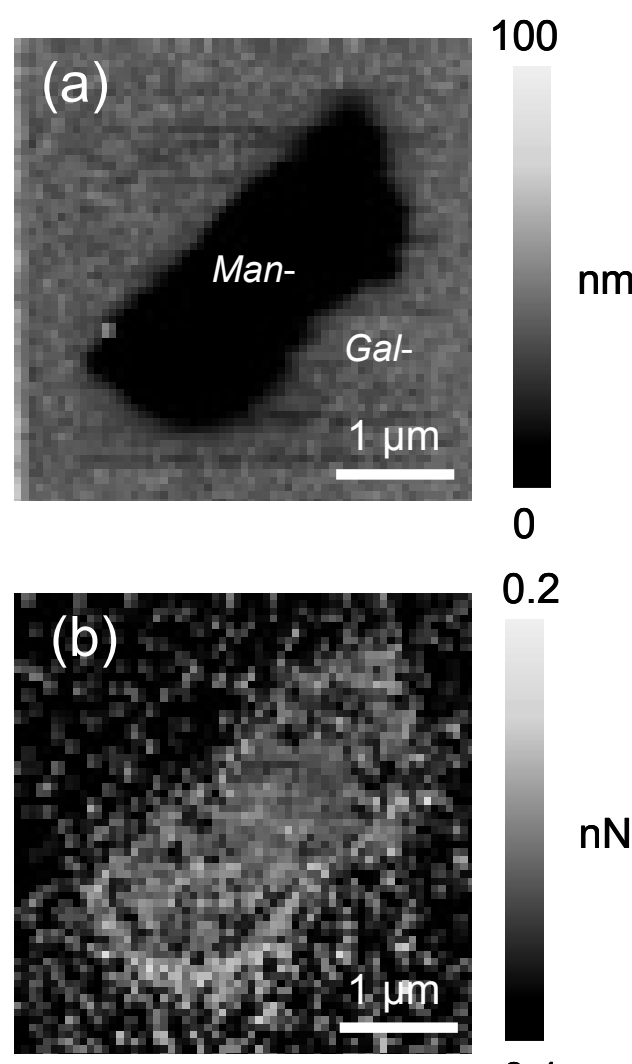

0.2

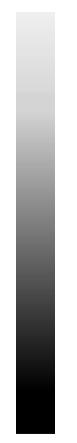

0.1

Figure 7. (a) Topological image and (b) adhesion force image of the Man/Gal-terminated patterned surface obtained with a ConA-modified tip in a PBS solution.

\subsection{Evaluation of spatial resolution}

The spatial resolution was evaluated using a sugar-patterned surface fabricated by colloidal lithography using silica nanoparticles with two different diameters (50 and $100 \mathrm{~nm}$ ) as a mask. Figure 8 shows topological images and adhesion force images of the $O E G / M a n$-terminated nanopatterned surfaces in a PBS solution.
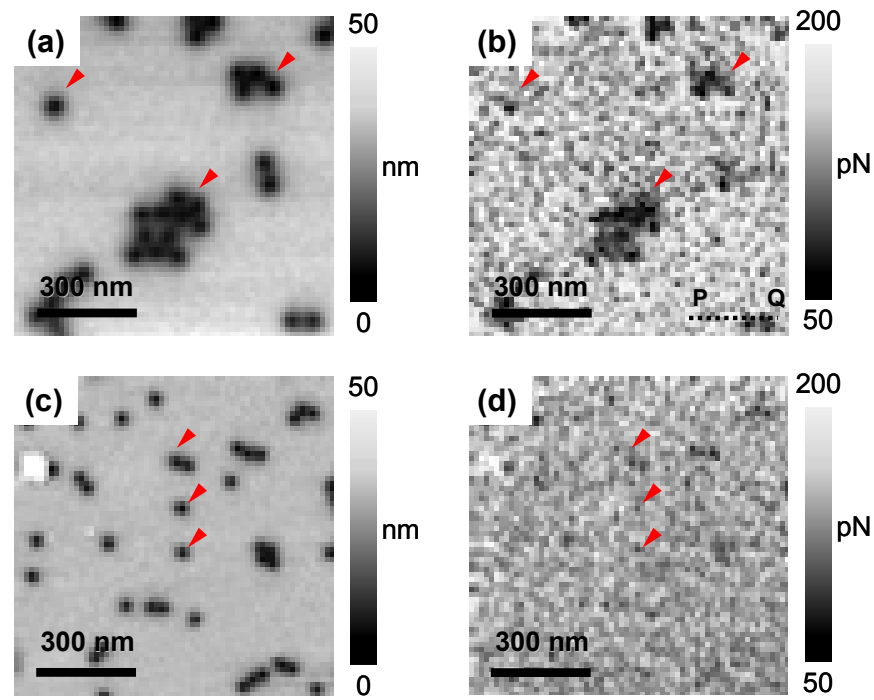

(e)

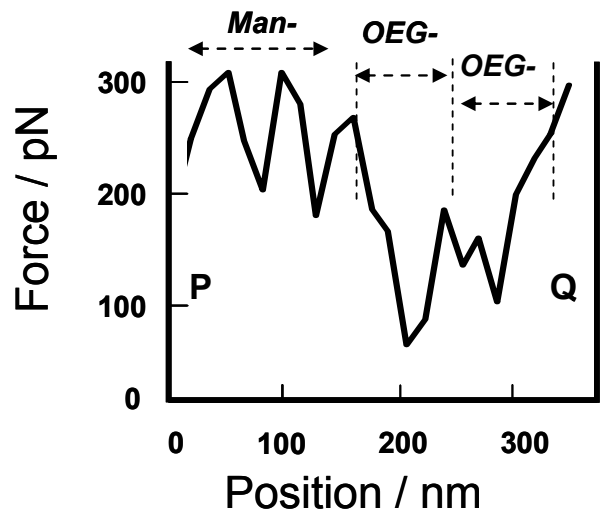

Figure 8. (a) Height and (b) adhesion force images of $O E G / M a n$-terminated nanopattern surface fabricated using 100-nm-diameter silica nanoparticles. (c) Height and (d) adhesion force images of the OEG/Man-terminated nanopattern surface fabricated using 50 -nm-diameter silica nanoparticles. Arrows in the image indicate nanopatterned regions fabricated by silica nanoparticles. (e) Force line-profile of dotted P-Q line in (b). Man and $O E G$ region are clearly distinguished.

In the topological images, the relatively high region is the Man-terminated region and the low region is the $O E G$-terminated region. Using the nanopatterned surface fabricated using 100-nm-diameter silica nanoparticles, it was confirmed that Man-terminated regions could be clearly identified by adhesion force 
mapping (Figure 8b). In contrast, Man-terminated regions could not be clearly visualized for the nanopatterned surface fabricated using 50-nm-diameter silica nanoparticles (Figure 8d). This is presumably due to the non-negligible interactions with Man in the hole sidewalls, even when measuring a $O E G$-terminated region in the hole, because the tip diameter $(10-20 \mathrm{~nm})$ is very similar to the hole size. Furthermore, due to the size of ConA attached to the tip via an $O E G$ chain, it would appear to be difficult to accurately detect regions that are several tens of nanometers in size using a ConA-modified AFM tip. Therefore, this method was determined to have an effective spatial resolution of approximately $100 \mathrm{~nm}$.

\section{Conclusion}

Precisely sugar-patterned surfaces were fabricated by lithography and their two-dimensional distributions were successfully visualized in a PBS solution by AFM force measurements with a ConA-modified tip. Man-terminated regions could be distinguished from $P P C$-terminated regions on a surface that resembles a biological membrane. In addition, Man-terminated regions could also be distinguished from Gal-terminated regions, which demonstrates that target sugar chains can be selectively detected using an AFM tip chemically modified by the corresponding lectin. The spatial resolution of this technique was estimated to be approximately $100 \mathrm{~nm}$ using an $O E G / M a n$-terminated nanopatterned surface fabricated using silica nanoparticles. We believe that the method proposed in this study will be used for distribution analysis of sugar chains in lipid rafts (size of lipid rafts: dozen nanometers to several micrometers in diameter) in the near future.

\section{References}

[1] A.Varki, Glycobiology 3, 97 (1993).

[2] P. Gagneux, A. Varki, Glycobiology 9, 747 (1999).

[3] B. K. Brandley, R. L. Schnaar, J. Leukoc. Biol. 40, 97 (1986).

[4] A. Kameyama, N. Kikuchi, S. Nakaya, H. Ito, T. Sato, T. Shikanai, Y. Takahashi, K. Takahashi, H. Narimatsu, Anal. Chem. 77, 4719 (2005).

[5] H. Ito, A. Kameyama, T. Sato, K. Kiyohara, Y. Nakahara, H. Narimatsu, Angew. Chem. Int. Ed. 44,
4547 (2005).

[6] S. W. Hell, J. Wichmann, Opt. Lett. 19, 780 (1994).

[7] S. W. Hell, Science 316, 1153 (2007).

[8] T. Murai, Y. Maruyama, K. Mio, H. Nishiyama, M. Suga, C. Sato, J. Biol. Chem. 286(3), 1999 (2011).

[9] G. Binnig, C. F. Quate, C. Gerber, Phys. Rev. Lett. 56, 930 (1986).

[10] (a) H. Schönherr, M. W. J. Beulen, J. Bügler, J. Huskens, F. C. J. M. van Veggel, D. N. Reinhoudt, G. J. Vancso, J. Am. Chem. Soc. 122, 4963 (2000). (b) S. Zapotoczny, T. Auletta, M. R. de Jong, H. Schönherr, J. Huskens, F. C. J. M. van Veggel, D. N. Reinhoudt, G. J. Vancso, Langmuir 18, 6988 (2002). (c) T. Auletta, M. R. de Jong, A. Mulder, F. C. J. M. van Veggel, J. Huskens, Reinhoudt, D. N.; Zou, S.; Zapotoczny, S.; H. Schönherr, G. J.Vancso, L. Kuipers, J. Am. Chem. Soc. 126, 1577 (2004).

[11] (a) S. Kado, K. Kimura, J. Am. Chem. Soc. 125, 4560 (2003). (b) S. Kado, K. Yamada, K. Kimura, Langmuir 20, 3259 (2004).

[12] R. Eckel, R. Ros, B. Decker, J. Mattay, D. Anselmetti, Angew. Chem., Int. Ed. 44, 484 (2005). [13] (a) S. Allen, J. Davis, A. C. Dawkes, M. C. Davis, J. C. Edwards, M. C. Parker, C. J. Roberts, J. Sefton, S. J. B. Tendler, P. M. Williams, FEBS Lett. 390, 161 (1996). (b) S. S. Wong, E. Joselevich, A. T. Woolley, C. L. Cheung, C. M. Lieber, Nature 394, 52 (1998). (c) C. Yuan, A. Chen, P. Kolb, V. T. Moy, Biochem. 39, 10219 (2000).

[14] (a) U. Dammer, M. Hegner, D. Anselmetti, P. Sagner, M. Dreier, W. Huber, H. J. Guntherodt, Biophys. J. 70, 2437 (1996). (b) Y. Harada, M. Kuroda, A. Ishida, Langmuir 16, 708 (2000).

[15] A. Touhami, B. Hoffmann, A. Vasella, F. A. Denis, Y. F. Dufrêne, Langmuir 19, 1745 (2003).

[16] (a) M. Rief, M. Gautel, F. Oesterhelt, J. M. Fernandez, H. E. Gaub, Science 276, 1109 (1997). (b) T. M. Fisher, P. E. Marszalek, J. M. Fernandez, Nat. Struct. Biol. 7, 719 (2000). (c) A. F. Oberhauser, M. Carrion-Vazquez, J. Biol. Chem. 283, 6617 (2008).

[17] Y. Bustanji, C. R. Arciola, M. Conti, E. Mandello, L. Montanaro, B. Samori, Proc. Natl. Acad. Sci. U.S.A. 100, 13292 (2003).

[18] E. A. Evans, D. Calderwood, Science 316, 1148 (2007). 
[19] H. Lis, N. Sharon, Chem. Rev. 98, 637 (1998).

[20] (a) M. Lekka, P. Laidler, J. Dulinska, M. Labedz, G. Pyka, Eur. Biophys. J. Biophys. Lett. 33, 644 (2004).

(b) T. V. Ratto, K. C. Langry, R. E. Rudd, R. L. Balhorn, M. J. Allen, M. W. McElfresh, Biophys. J. 86, 2430 (2004).

[21] (a) V. Dupres, F. D. Menozzi, C. Locht, B. H. Clare, N. L. Abbott, S. Cuenot, C. Bompard, D. Raze, Y. F. Dufrêne, Nat Methods 2, 515 (2005). (b) Y. Gilbert, M. Deghorain, L. Wang, B. Xu, P. D. Pollheimer, H. J. Gruber, J. Errington, B. Hallet, X. Haulot, C. Verbelen, P. Hols, Y. F. Dufrêne, Nano Lett. 7, 796 (2007).

[22] S. Inoue, Y. Nakahara, S. Kado, M. Tanaka, K. Kimura, J. Surf. Anal. 17, 328 (2011).

[23] L. Likhosherstov, O. Novikova, V. A. Derveitskaja, N. K. Kochetkov, Carbohydr. Res. 146, c1 (1986).

査読コメント

\section{查読者 1. 青柳里果（島根大学）}

The manuscript describes chemically modified AFM for detecting a particular sugar chains. I have same comments:

\section{[查読者 1-1]}

Although it is indicated that the specific affinity of the modified AFM is effective for detecting the particular sugar, mannose, it is not mentioned if the method is feasible to detect real biological membranes or not. Please explain sizes of the target sugar chains in the biological membranes.

\section{[著者]}

Thank you for your comments. Target sugar chains on biological membranes are "lipid rafts" domain. Lipid rafts are several dozen nanometers to several micrometers. In this study, we showed that the spatial resolution of our technique was approximately $100 \mathrm{~nm}$. So, we think that the method proposed in this study will be used for distribution analysis of sugar chains in lipid rafts in the near future.

\section{[査読者 1-2］}

Since proteins are supposed to be much larger than sugar chains, it would be difficult to detect a particular
[24] M. Tanaka, T. Sawaguchi, Y. Sato, K. Yoshioka, O. Niwa, Tetrahedron Lett. 50, 4092 (2009).

[25] M. Radmacher, J. P. Cleveland, M. Fritz, H. G. Hansma, P. K. Hansma, Biophys. J. 66, 2159 (1994).

[26] (a) X. Zhang, V. K. Yadavalli, Anal. Chim. Acta. 649,1 (2009). (b) T. P. Sullivan, W. T. S. Huck, Eur. J. Org. Chem. 17 (2003). (c) S. Flink, F. C. J. M. van Veggel, D. N. Reinhoudt,Adv. Mater. 12, 1315 (2000).

[27] (a) K. Ishihara, T. Ueda, N. Nakabayashi, Polymer J. 22, 355 (1990). (b) K. Ishihara, H. Nomura, T. Mihara, K. Kurita, Y. Iwasaki, N. Nakabayashi, $J$. Biomed. Mater. Res. 39, 323 (1998).

[28] (a) M. Akiyama, M. Fujita, M. Fujihira, Chem. Lett. 35, 1112 (2006). (b) S. Kado, H. Yano, Y. Nakahara, K. Kimura, Chem. Lett. 38, 58 (2009).

sugar on the membranes. Please mention your strategies to achieve enough spatial resolution using protein-modified tips.

\section{[著者］}

Thank you for your comment. As you know, in an AFM imaging, spatial resolutions are dependent on the probe size. So, it is very difficult to detect a single sugar chain at this stage. However, that point is one of the important technological opportunities, the development of another detection technique using a low molecular weight of host compound is underway.

\section{[査読者 1-3]}

Are there any solutions to detect unknown sugar on the membrane?

\section{[著者]}

It is very difficult to detect an unknown sugar chain at this stage, because our method is based on the detection of the specific interaction force between sugar recognition protein and "particular" sugar chain. This technical issue remains as one of the important key problems to be solved. 


\section{查読者 2. 藤平正道（東京薬科大学薬学部 客員教 授, 東京工業大学 名誉教授)}

生体試料表面を模した，人工的な表面を作製し， 糖鎖の化学識別を AFM で明確に観察した点は大 いに評価されて良いと判断します。但し，以下の 点を改訂されたらさらに良い論文になると思わ れます。

\section{[査読者 2-1]}

二つの異なった化学組成を持ち，かつ，一方の 領域が $10 \mu \mathrm{m} \sim 100 \mathrm{~nm}$ スケールの部分表面からな る試料の調製法の説明が理解しにくい. 理解を困 難にする理由の一つに, Figure 2 の調製の説明図 が Results and discussion の 3.1 で初めて出てくるこ とにあります。この図の後に, $2.2,2.3$ 及び 2.4 の Experimental の記述がくれば，この調製法に不慣 れな読者も容易に理解できると思われます.

\section{[著者]}

2.2 項の文頭に Figure 2 の説明図を示すように追 記修正しました。 また, Figure 2 の位置を 2.2 項の 前にレイアウト変更しました。

\section{[査読者 2-2］}

何故, 溶液中のチオール類による自己組織化膜 （SAM）形成法を用いて本研究の目的を達成しよ うとしたかの動機が明確に記述されていません. 出来れば簡単な説明を加えた方が良いと思われ ます．充分な時間がなければ，次回にはこの方法 を用いる意義を明確にされることをお勧めしま す.

\section{[著者]}

3.1 項の文頭に，自己組織化膜（SAM）を用い た簡単な説明を追記しました。

\section{[查読者 2-3]}

金表面の化合物 1 3 3 によ SAM 形成はかなり 確立した表面化学修飾法であるので, 本文 (2.2 2.4）中の記述で充分であると思われますが, Man の導入に関する記述は少なくとも反応時間の記 述が必要と思われます。このままでは他の研究者 の追試は困難です．もしこの研究が継続されるの であれば，いずれは（次の論文では） Man， Gal, およびConA が化合物 2 の SAM 表面へ導入された 事を示す，他の手法による表面分析結果の提示が 望まれます. 今回の力測定の結果が導入を示して いると言うのでは，本法による糖鎖識別法の提案 の意義を弱めます．何故，このようなコメントを
するかというと，その背景には「高密度に充填さ れた化合物 3 に囲まれ, 埋もれた化合物 2 の - $\mathrm{COOH}$ 末端はさらなる表面修飾反応に関与でき るのか?」という疑問からです.Man，Gal，およ び ConA の面密度の知見もより定量的な議論には 必要になると思われます。

\section{[著者］}

実験項に反応時間の記述を追記しました.

また，ご指摘の通り，Man, Gal, および ConA が SAM 表面へ導入されたことに関する実験的証 拠を得ることが必要です．現在も表面分析法を用 いた検討をいくつか行っていますが，今のところ 固定化されていることを示す直接的な実験的証 拠は得られておりません.

ConA の固定化については, 現在のところ以下の ように重㸚て検証しています。

(i) 金基板に ConA を修飾した後に，飛行時間型 二次イオン質量分析計（TOF-SIMS）を用いて基 板表面から得られるマススペクトルを解析した 結果, ConA (タンパク質) 由来のフラグメントイ オン $\mathrm{CN}^{-}(m / z 26)$ が高強度で得られることを確 認しました．よって, ConA が金基板に固定化され ていることが示唆されます.

(ii) ConA 修飾探針を用いて基板に固定化された マンノースのセンシングを行い, 特徵的なフォー スカーブが得られている測定系中に, フリーのマ ンノースを導入すると, 特徵的なフォースカーブ が得られなくなることを確認しました（ブロッキ ング試験)。このことは, 探針に修飾した ConA に フリーのマンノースが結合して, 基板表面のマン ノースと結合できなくなっていることを示唆し ています，すなわち，探針には ConA が修飾され ているものと判断されます.

(iii) ConA を探針に修飾していない場合, Man と ConA 間に働く特徵的な相互作用力が得られない ことを確認しています. 寸なわち, 本報告で示し たConA-Man の相互作用力は, Con A が固定化さ れた探針と Man との相互作用力であると判断さ れます。

Man や Gal についても同様に, 固定化前後で得 られるフォースカーブを比較した結果, 固定化後 にのみ特徵的な相互作用力が得られました。また, TOF-SIMS 測定を行い, 糖鎖分子の直接検出につ 
いて検討しましたが，糖鎖分子イオンは検出され ませんでした，糖鎖を検出するためには表面分析 的な工夫（ソフトイオン化等）が必要と考えてお り，TOF-SIMS や表面分析の専門家の皆様と議論 し，検討を進めたいと考えております．

\section{[査読者 2-4]}

Ref. 25 では上記の理由で, 走査速度は $0.1 \mathrm{~Hz}$

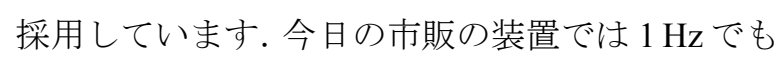
像を撮れるのですか?

\section{[著者]}

本論文で示している走査速度 $(1 \mathrm{~Hz})$ は，フォ ースカーブ取得時の走査速度です. 走査速度は, $0.01 \sim 100 \mathrm{~Hz}$ 程度まで変化させることができ，こ れは過去から現在に至るまで大きく変化してお りません. Hansma らの走查速度 $0.1 \mathrm{~Hz}$ という記 述は, マッピング像を得る際の水平方向の走查速 度ですので，ここで示したフォースカーブ測定の 走査速度の意味合いとは異なっております。

\section{[査読者 2-5]}

The reverse delay は $1 \mathrm{~s}$ とありますが，もしフォ ースカーブに関連する時間であれば， $1 \mathrm{~ms}$ ではあ りませんか? 見当違いかもしれませんが， force-volume 法に関する記述に関しては, Ref.25 の出版時と今日の時間差を考慮しますと，もう少 し丁寧に説明した方が読者には理解しや寸いの ではないでしょうか?

\section{[著者]}

本論文で記述しました” reverse delay”は，表面 に探針が接触した後にそのまま待機させる時間 を示しておりました（force-volume 法に付属する 機能).タンパク質の分子認識には時間依存性が あり，今回用いているConA と Man との相互作用 においては，1s 程度の時間接触させておくことが 分子を認識する上で重要となります。このような 背景に基づき, 生体認識の相互作用力研究に force-volume 法が多用されております。従って, pulse-force-mode AFM は高速で相互作用力像が得 られる大変有用な技術なのですが，本ターゲット においては不向きと判断しております.

なお, force-volume 法において, より一般的に 用いられている” surface delay”という記述に改め ました。

\section{[査読者 2-6]}

付着力は表面の凹凸によって分布を持つこと が知られています (F. Sato et al., Ultramicroscopy 97, 303 (2003)). 金の膜厚が厚くなると, 金凸部の半 径も増加し, 益々付着力の分布が広がり, 中心の 力の平均值も変化します。この結果は「AFM 探針 先端の球面と試料表面の凸部の上では球一球一 点接触で，表面の球に囲まれた凹部では探針先端 球が複数の表面球と多点接触することにより力 の分布が観測される」と説明されます．この観点 からは $50 \mathrm{~nm}$ は少々厚めかもしれません. 付着力 の凹凸依存性は Hasma らの文献 25 でも指摘され ています。今後は凹凸の影響も考慮して付着力測 定をされることをお勧めします。

\section{[著者]}

ご指摘頂いた点は, 今後付着力の定量的な議論 を深めていく際に極めて重要であると思います. 今後の検討では, 凹凸の影響を出来るだけ低減で きるような試料調製法を検討していきたいと考 えております. その手段の一つとして, 今回ご教 示頂いた金の膜厚制御を行い, 系統的に評価を行 っていきたいと考えております. 